\title{
Model Pendampingan Pembelajaran Daring saat Pandemi Covid-19
}

\author{
Muhammad Khosyi'in ${ }^{1 *}$, Eka Nuryanto Budisusila² \\ 1,2Teknik Elektro, Fakultas Teknologi Industri, Universitas Islam Sultan \\ Agung, Jl. Raya Kaligawe Km.4, Semarang 50112. Telp : (024) 6583584/6582455, \\ chosyi@unissula.ac.id, ekanbs@unissula.ac.id
}

* Korespondensi : chosyi@unissula.ac.id

Diterima: 3 November 2021; Review: 4 November 2021 ; Disetujui: 26 Desember 2021 ; Diterbitkan: 31 Desember 2021

\begin{abstract}
The government's appeal regarding the Covid-19 pandemic to carry out online learning through video conferences, digital documents and other online means is not without problems. Lack of knowledge about media use, especially the use of Information and Communication Technology, is the biggest problem. The program organized to solve these obstacles is to carry out online learning mentoring activities. The mentoring program began by holding an online Forum Group Discussion to obtain information on the needs and constraints of teachers in conducting online learning. The action continued with filling out questionnaires about the implementation of online learning to get information on online learning models carried out by teachers. From the questionnaire, ten teachers were identified who later became participants in learning assistance. Scheduled mentoring is carried out online for three days with the Zoom material for Video Conference, the use of the classroom for online classes, and google forms to create simple quizzes. Unscheduled mentoring is carried out from before the training until all teachers can implement the online learning model provided. The results of the mentoring show that these activities are beneficial and have been implemented in the online learning process. The Zoom application is the most widely used platform in online learning. The problem faced by the participants were related to data connections and internet network infrastructure.
\end{abstract}

Keywords : Covid-19, online learning, zoom, classroom, google form, quiz

\begin{abstract}
Abstrak
Himbauan pemerintah berkaitan pandemi Covid-19 untuk melaksanakan pembelajaran secara daring melalui Video Conference, dokumen digital dan sarana daring lainnya bukan tanpa kendala. Kurangnya pengetahuan mengenai penggunaan media khususnya pemanfaatan Teknologi Informasi dan Komunikasi menjadi kendala paling besar. Program yang diselenggarakan untuk menyelesaikan kendala tersebut adalah dengan melaksanakan kegiatan pendampingan pembelajaran daring. Program pendampingan dimulai dengan mengadakan Forum Group Discussion secara daring untuk mendapatkan informasi kebutuhan dan kendala guru dalam menyelenggarakan pembelajaran daring. Kegiatan berlanjut dengan pengisian kuisioner tentang penyelanggaraan pembelajaran daring untuk memperoleh informasi model pembelajaran daring yang dilakukan para guru. Dari kuisoner tersebut teridentifikasi sepuluh orang guru yang kemudian menjadi peserta pendampingan pembelajaran. Pendampingan terjadwal dilakukan secara daring selama tiga hari dengan meteri Zoom untuk Video Conference, penggunaan classroom untuk kelas daring dan penggunaan google form untuk membuat kuis sederhana. Pendampingan tidak terjadwal dilaksanakan dari sebelum pelatihan sampai semua guruguru dapat mengimplementasikan model pembalajaran daring yang diberikan. Hasil
\end{abstract}


pendampingan menunjukkan bahwa kegiatan tersebut sangat bermanfaat dan telah diimplementasikan dalam proses pembelajaran online. Aplikasi Zoom menjadi platform yang paling banyak digunakan dalam pembelajaran online. Adapun kendala yang dihadapi para peserta adalah terkait koneksi data dan infrastruktur jaringan internet.

Kata kunci : Covid-19, pembelajaran daring, zoom, classroom, google form, kuis

\section{PENDAHULUAN}

Sejalan dengan kemajuan teknologi informasi dan komunikasi, kini pendekatan pembelajaran telah berubah ke arah pembelajaran abad pengetahuan. Orang dapat belajar di mana saja, kapan saja, dengan siapa saja. Itulah ciri pembelajaran abad pengetahuan yang dikenal sebagai berbasis komputer. Penelitian ini bertujuan untuk mengembangkan model pembelajaran daring atau Online Learning Model (OLM) (Kuntarto, 2017).

Pada kondisi normal, model pembelajaran di sekolah khususnya di Sekolah Dasar ataupun menengah tidak pernah meninggalkan peran guru di dalam kelas, penggunaan teknologi informasi dan komunikasi menjadi media yang sangat penting dalam proses penyampaian materi dari guru ke para siswa, salah satunya dengan menggunakan media e-learning. Melalui pemanfaatan media elektronik untuk kegiatan pembelajaran (elearning), peserta didik dapat memperoleh kemudahan dan keluwesan dalam berinteraksi dengan bahan/materi pelajaran. Demikian juga interaksi antara peserta didik dengan guru/ atau interaksi antara sesama peserta didik. Peserta didik dapat saling berbagi informasi atau pendapat mengenai berbagai hal yang menyangkut materi pelajaran ataupun kebutuhan di bidang pengembangan diri peserta didik (Siahaan, 2008).

Dalam ikhtiar pencegahan terhadap perkembangan dan penyebaran Corona Virus Desease (Covid-19), Kementrian memberikan himbauan untuk memberlakukan pembelajaran secara daring dari rumah bagi siswa dan mahasiswa. Para guru juga diberikan himbauan untuk aktifitas mengajar atau memberikan materi dari rumah (Bekerja Dari Rumah / BRD) melalui Video Conference, dokumen digital dan juga sarana daring lainnya (Menteri Pendidikan dan Kebudayaan Republik Indonesia, 2020). Yayasan Pusat Kajian dan Pengembangan Islam (YPKPI) Masjid Raya Baiturrahman Semarang yang memiliki beberapa unit sekolah, antara lain, $\mathrm{KB} / \mathrm{TK} \mathrm{Hj}$. Isriati Baiturrahman 1 dan 2, SD $\mathrm{Hj}$. Isriati Baiturrahman Semarang 1 dan 2, SMP Hj. Isriati Baiturruhman dan juga SMK Islamic Center Baiturrahman (Yayasan Pusat Kajian dan Pengembangan Islam (YPKPI) Masjid Raya Baiturrahman Jawa Tengah, 2012), secara langsung juga merasakan dampak dari pandemi Covid-19 ini. Diperlukan sebuah observasi untuk menggali informasi mengenai kendala yang dihadapi para guru berkaitan dengan permasalahan dan kebutuhan dalam mengimplementasikan pembelajaran secara daring tersebut.

Dibutuhkan solusi pemecahan permasalahan yang konstruktif dan realistis untuk dilakukan. Untuk menyikapi pembelajaran model jarak jauh/daring, guru harus menguasai model aplikasi yang memungkinkan kegiatan pembelajaran jarak jauh/daring. Aplikasi yang digunakan oleh guru tentunya juga mudah digunakan para siswa, sehingga proses pembelajaran berjalan dengan baik dan tetap dapat mengakomodir kebutuhan siswa dalam melakukan diskusi terutama untuk pelajaran yang dianggap membutuhkan penjelasan dan pemahaman yang lebih mendalam.

\section{ANALISIS SITUASI}

Melihat situasi dan kondisi saat pandemi covid-19 tersebut, diperlukan terobosan agar para guru tetap dapat mengajar dengan optimal dari rumah masing-masing. Para guru harus mampu memiliki keterampilan dalam bidang Teknologi Informasi dan Komunikasi (TIK), karena hal tersebut menjadi bagian penting bagi seorang pendidik agar mampu memfasilitasi siswa ketika belajar (Sadikin et al., 2020). Observasi yang dilakukan kepada beberapa orang guru pada sekolah di lingkungan YPKPI Masjid Raya Baiturrahman Semarang, diperoleh data bahwa tidak semua guru dapat mengajar 
dengan optimal dari rumah karena terkendala beberapa hal, salah satunya adalah kurangnya pengetahuan mengenai penggunaan media, khususnya pemanfaatan TIK.

Terdapat banyak pendapat berbeda mengenai penggunaan e-learning dalam pembelajaran di sekolah, beberapa sekolah tetap menjalankan proses pembelaran secara konvensional, beberapa yang lain menggunakan model blended learning (Pramasdyahsari et al., 2020). Dengan kemajuan teknologi seperti adanya internet, pembelajaran dapat dilakukan dalam jaringan (daring) atau kombinasi antara tatap muka dan daring. Banyak manfaat yang bisa diambil apabila pembelajaran daring ini diterapkan baik untuk institusi pendidikan. (Isman, 2017).

Tria Mardiana dalam artikelnya menyampaikan bahwa Evaluasi masih sering menjadi bagian dalam kegiatan pembelajaran yang melelahkan, dari pembuatan soal sampai dengan melakukan koreksi pada lembar jawab. Dari kegiatan pengabdian yang dilakukan dengan materi penggunaan google form, diperoleh beberapa hasil antara lain, guru mengenal sistem evaluasi berbasis daring melaui Google Form, guru mampu menyusun soal berbasis daring dengan model assessment mandiri (Mardiana \& Arif Wiyat Purnanto, 2017). Kegiatan pengabdian yang dilaksanakan Vicky Dwi Wicaksono dan Putri Rachmadyant memberikan suatu kesimpulan bahwa, penyelenggaran google classroom di Sekolah Dasar tanpa menyesampingkan proses pembelajaran konvensional yang dilakukan merupakan contoh hasil implementasi yang baik dari metode blended learning, dimana menggabungkan dua metode pembelajaran konvensional dan daring untuk membuat siswa merasa nyaman dan aktif dalam mengonstruksi pengetahuannya. Guru dapat memanfaatkan berbagai fitur yang terdapat pada googleclassroom seperti assigments, grading, communication, time-cost, archive course, mobileapplications, dan privacy (Wicaksono \& Rachmadyanti, 2016).

Penggunaan aplikasi google classroom, telah terbukti dapat menjadi alternatif yang sangat mudah dan efektif untuk guru dalam menjalankan model pembelajaran blended learning, sehingga disaat pandemi covid-19 ini, aplikasi ini dapat menjadi solusi bagi guru dalam menggantikan model kelas konvensional di dalam ruangan (Wicaksono \& Rachmadyanti, 2016). Termasuk di dalamnya adalah penggunaan aplikasi google form untuk kebutuhan pembuatan kuis atau soal secara online berikut dengan metode evaluasi dan penilaiannya (Mardiana \& Arif Wiyat Purnanto, 2017; Wicaksono \& Rachmadyanti, 2016). Kebutuhan guru untuk dapat menjelaskan materi ajar secara lebih jelas dan lugas menjadi sebuah keharusan, dimana kondisi tersebut harus dilakukan dengan model pembelajaran secara sinkron, untuk mengatasi hal tersebut, aplikasi Zoom Cloud Meetings dapat menjadi solusi sebagai media pembelajaran daring yang memungkinkan guru berinteraksi lebih komunikatif. (Suminingsih, n.d.). Sehingga aplikasi zoom menjadi salah satu aplikasi yang dapat digunakan oleh guru sebagai sarana komunikasi dengan para siswa.

\section{METODE PELAKSANAAN}

Metode yang dilakukan adalah dengan melakukan beberapa tahapan kegiatan yang ditunjukkan dalam diagram alir berikut: 


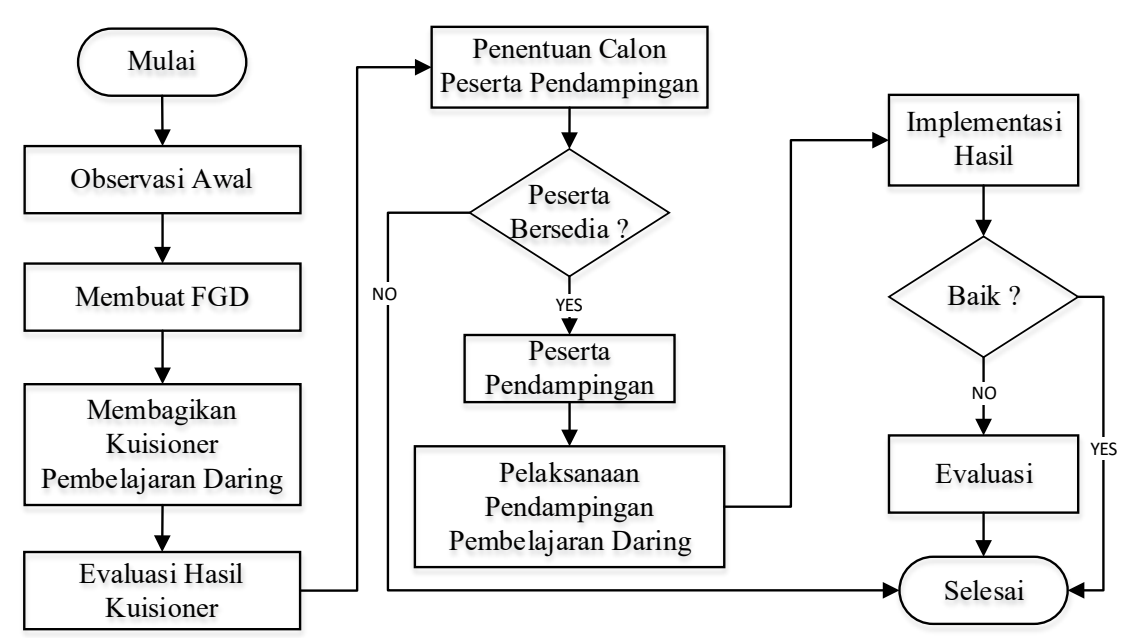

Gambar 1. Diagram Alir Pendampingan Pembelajaran Daring

Kegiatan Pendampingan dimulai dengan melakukan observasi Awal untuk mengumpulkan data awal kendala dari para guru-guru dan sekolah terkait dengan penyelanggaraan pembelajaran daring. Tahapan selanjutnya adalah melaksanakan Forum Group Discussion dengan beberapa guru berkaitan dengan kendala dan kebutuhan guru dalam pembelajaran daring. Hasil observasi diperkuat dengan hasil kuisioner ini dibuat secara online menggunakan aplikasi google form, berisi tentang pengalaman dan kendala selama melaksanakan model pembelajaran daring, kuisioner ini dibagikan kepada para guru di lingkungan YPKPI untuk kemudian diolah dan dilakukan kajian perlu dan tidaknya serta siapa saja yang akan diikutkan dalam kegiatan pendampingan pembelajaran daring.

Kegiatan Pendampingan ini dilaksanakan secara daring meggunakan aplikasi zoom. Pendampingan ini terbagi atas dua model yaitu pendampingan terjadwal dan pendampingan tidak terjadwal. Setelah kegiatan pendampingan terjadwal selesai, para guru diminta untuk mengimplementasikan hasil pendampingan yang sudah berjalan dengan membuat materi belajar secara daring mengguanakan aplikasi yang sudah ditentukan.

\section{HASIL DAN PEMBAHASAN}

Pada bagian ini, dijelaskan hasil implemantasi dari program pengabdian atau pemberdayaan masyarakat berupa hasil atau kebermanaatan program dan pada saat yang sama diberikan pembahasan yang komprehensif. Hasil dapat disajikan dalam angka, grafik, tabel dan lain-lain yang membuat pembaca memahami dengan mudah. Pembahasan dapat dibuat dalam beberapa sub-bab.

\subsection{Penjaringan Peserta}

Hasil penjaringan calon peserta yang dilakukan secaring daring dengan meminta para guru untuk mengisi Kuisioner mengenai Sharing Pembelajaran Daring di Lingkungan YPKPI Baiturrahman Semarang (kecuali SD Hj. Isriati Baiturrahman 2 karena sekolah telah ada program sejenis), diperoleh bahwa unit sekolah yang guru-gurunya berpartisipasi mengisi kuisioner paling banyak adalah dari SD Hj, Isriati 1 Baiturrahman Semarang dengan jumlah 45\%, SMK Islamic Center Baiturrahman berjumlah 33,3\%, $\mathrm{KB} / \mathrm{TK} \mathrm{Hj}$. Isriati Baiturrahman 1 berjumlah 2 18,3\%, KB/TK Hj. Isriati Baiturrahman 2 dan SMP Isriati sejumlah 1,7\%.

Dari seluruh peserta penjaringan, $60 \%$ menggunakan smartphone dan komputer/laptop dalam mengajar, 35\% menggunakan komputer /laptop dan sisanya menggunakan perangkat smartphone. Sebagian besar guru menggunakan Group WhatsApp sebagai sarana dalam pembelajaran daring dengan menggunakan koneksi internet dari Tethering HP/Hotspot Portabel. 


\subsection{Identifikasi Peserta Pendampingan}

Tahapan selanjutnya adalah mengidentifikasi guru yang berpotensi untuk mengikuti pendampingan. Dari seluruh guru yang mengisi kuisioner sebelumnya diperolah $20 \%$ guru yang belum pernah menggunakan aplikasi Video Conference, data awal inilah yang kemudian dilakukan tindakan lebih lanjut berupa konfirmasi kesediaan guru tersebut mengikuti pendampingan. Terdapat 11 orang guru yang mengisi kesanggupan dengan 10 orang guru bersedia mengikuti pendampingan dan 1 orang guru tidak bersedia mengikuti kegiatan pendampingan $(90,9 \%$ guru bersedia mengikuti kegiatan pendampingan)

\subsection{Pelaksanaan Pendampingan}

Kegiatan Pendampingan ini meggunakan aplikasi zoom. Pendampingan ini terbagi atas dua model

a. Pendampingan Terjadwal

Kegiatan pendampingan pembelajaran daring bagi guru-guru saat pandemi covid-19 telah direalisasikan dengan jadwal sebagai berikut:

Tabel 1. Agenda pendampingan terjadwal

\begin{tabular}{|c|c|c|c|c|}
\hline \\
\hline Hari ke- & $\begin{array}{l}\text { Hari } \\
\text { Tanggal }\end{array}$ & Jam & Tema & Materi \\
\hline 1. & $\begin{array}{l}\text { Kamis, } \\
16 \text { April } \\
2020\end{array}$ & $10.00-12.00$ & Zoom & $\begin{array}{l}\text { Membuat jadwal meeting } \\
\text { Conference } \\
\text { Mengundang siswa untuk } \\
\text { melakukan Video Conference } \\
\text { Interaksi saat Video Conference }\end{array}$ \\
\hline 2. & $\begin{array}{l}\text { Jum'at, } \\
17 \text { April } \\
2020\end{array}$ & $10.00-12.00$ & Classroom & $\begin{array}{l}\text { Mempersiapkan Class } \\
\text { Menambahkan Materi Ajar } \\
\text { Menambahkan Siswa } \\
\text { Membuat Penugasan }\end{array}$ \\
\hline 3. & $\begin{array}{l}\text { Sabtu, } \\
18 \text { April } \\
2020\end{array}$ & $10.00-12.00$ & $\begin{array}{l}\text { Google } \\
\text { Form }\end{array}$ & $\begin{array}{l}\text { Membuat Kuis Online } \\
\text { Mengirimkan Kuis Online ke Siswa } \\
\text { Mengelola Hasil Penilaian Kuis } \\
\text { siswa }\end{array}$ \\
\hline
\end{tabular}

Kegiatan pendampingan terjadwal sebagaimana pada tabel 1 dilaksanakan secara daring selama 3 hari dengan materi:

- Penggunaan aplikasi Zoom untuk Video Conference

- Penggunaan Classroom untuk kelas daring

- Penggunaan Google Form untuk membuat kuis sederhana

Semua materi disampaikan dengan media Video Conference dengan durasi waktu dua jam setiap hari. Materi tersebut juga dilengkapi dengan panduan yang dibagikan dalam format file digital dan juga video tutorial yang dapat diakes di youtube.

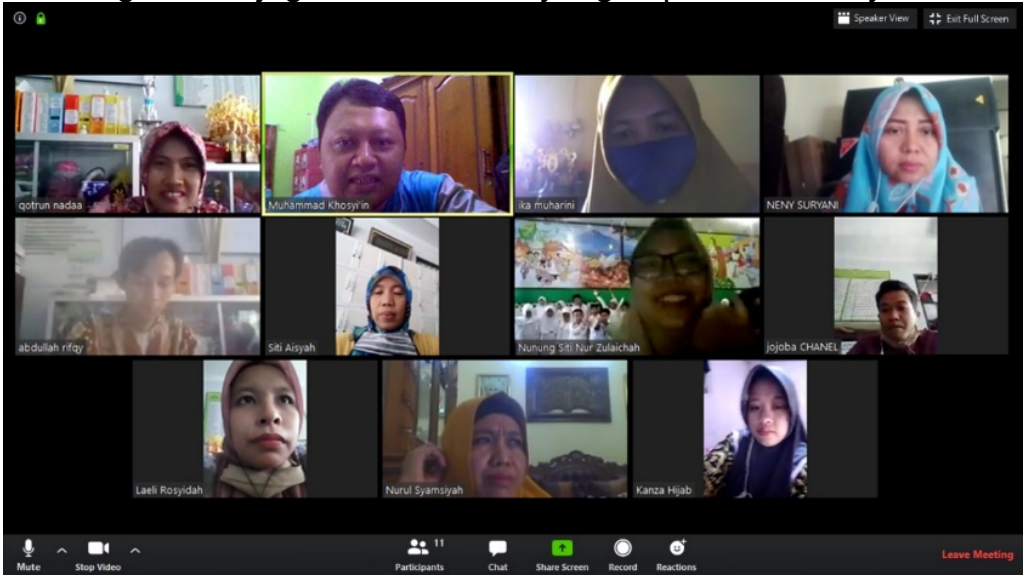

Sumber : Hasil Pelaksanaan (2021)

Gambar 2. Dokumentasi Pendampingan Pembelajaran Daring menggunakan Aplikasi Zoom 


\section{b. Pendampingan Tidak Terjadwal}

Metode pendampingan tidak terjadwal merupakan metode pendampingan yang dilaksanakan secara tentatif di luar jadwal yang sudah disepakati dengan menggunakan media daring, seperti whatsApp, email dan lain-lain. Kegiatan ini dimulai dari sebelum pelaksanaan pendampingan terjadwal sampai implementasi dan evaluasi dilakukan. Pendampingan dengan metode ini dilakukan untuk mengakomodir kebutuhan guru yang memiliki kendala pada saat menggunakan media pembelajaran secara daring.

Sesuai dengan kesepakatan, bahwa penyelanggaraan pendampingan pembelajaran daring yang terjadwal adalah menggunakan aplikasi zoom, pada saat menggunakan aplikasi ini diharapkan semua guru peserta pendampingan harus sudah memiliki akun Zoom dan juga email yang aktif serta dipastikan tidak terkendala dengan koneksi internet. Semua kendala oleh guru selalu dikomunikasikan dengan pendamping sebelum pelaksanaan pendampingan terjadwal.

Model pendampingan tidak terjadwal dilakukan dengan komunikasi yang aktif dan intensif antara guru dan pendamping, misalkan beberapa guru yang terkendala dengan keneksi internet, setelah dilakukan komunikasi teridentifikasi kendala tersebut disebabkan karena pengaturan pada konfigurasi jaringan laptop yang digunakan, karena itu guru diberikan pendampingan mengenai langkah-langkah yang harus dilakukan sendiri oleh guru tersebut sampai laptop dapat terhubung dengan jaringan internet. Guru yang terkendala dalam menggunakan dan mengimplementasikan materi pendampingan pembelajaran daring juga senantiasa dipandu sampai bisa.

\subsection{Implementasi Hasil}

Setelah kegiatan pendampingan, semua peserta diminta untuk mengimplementasikan hasil pendampingan dengan memberikan laporan berupa hasil implementasi model pembelajaran daring yang telah diimplementasikan. daring.

Berikut adalah contoh dokumentasi hasil implementasi pendampingan pembelajaran

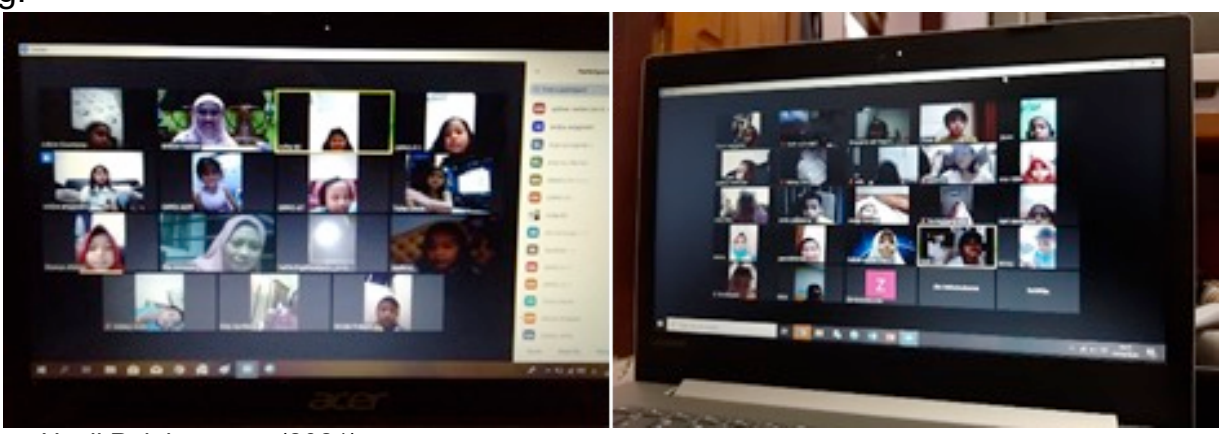

Sumber : Hasil Pelaksanaan (2021)

Gambar 3. Dokumentasi Implementasi Guru dalam melakukan Video Conference dengan Zoom

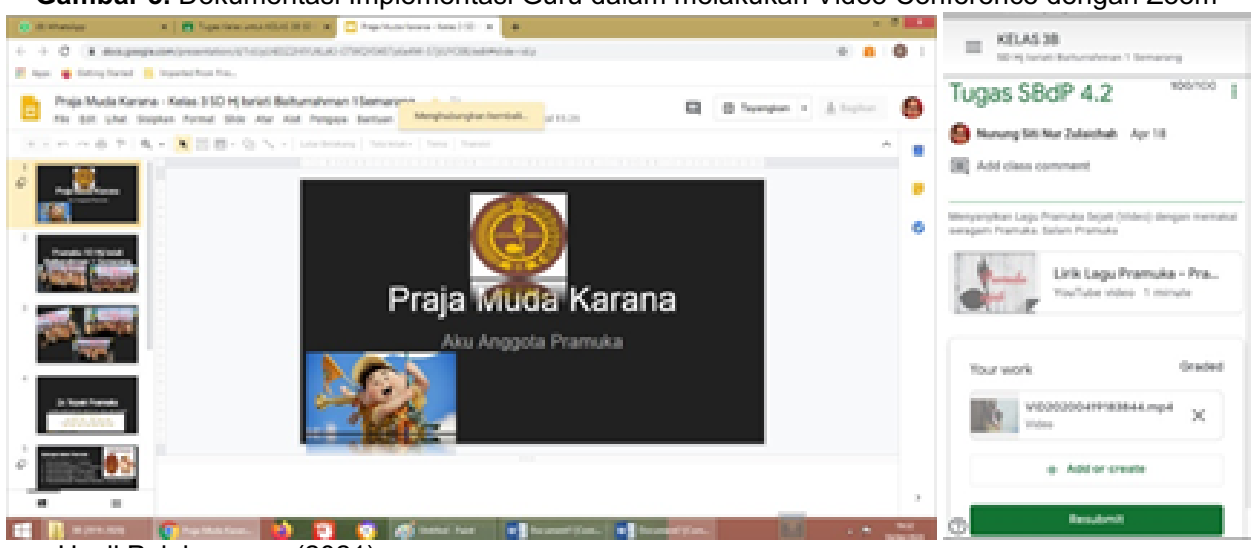

Sumber : Hasil Pelaksanaan (2021)

Gambar 4. Dokumentasi Implementasi Guru dalam menggunakan Classroom 


\subsection{Evaluasi Hasil}

Evaluasi kegiatan Pendampingan Pembelajaran Daring bagi guru-guru di lingkungan YPKPI Masjid Raya Baiturrahman ini dilakukan dengan melakukan monitoring kegiatan pembelajaran secara daring yang dilakukan peserta. Kendala yang terjadi pada saat implementasi, misalkan guru kesulitan dalam menggunakan aplikasi dan atau terkendala masalah lain, guru masih diberikan kesempatan untuk meminta pendampingan dari pendamping. Sebagai contoh adalah ketika salah satu guru peserta kesulitan ketika akan menjadi host aplikasi Zoom pada saat akan melaksanakan pembelajaran secara daring pada anak didik, maka ketika kendala tersebut disampaikan, pendamping akan memberikan pendampingan berupa langkah-langkah untuk menjalankan aplikasi zoom sebagai host, ini bisa dikategorikan sebagai bagian dari proses pendampingan tidak terjadwal.

Evaluasi juga diberikan dalam bentuk kuisioner, dimana peserta memberikan laporan berkaitan dengan kegiatan pembelajaran daring yang telah diimplementasikan oleh guru-guru.

Berikut adalah hasil evaluasi dari kuisioner yang diberikan, antara lain:

Seluruh peserta menyatakan bahwa kegiatan Pendampingan Pembelajaran Daring yang dilaksanakan Bulan April April 2020 Bermanfaat untuk Bapak/lbu Guru dan telah diimplementasikan dalam Kegiatan Belajar Mengajar.

Aplikasi yang paling banyak digunakan adalah Zoom (62,5\%) dan sisanya adalah menggunakan kolaborasi antara zoom, classroom dan googleform $(37,5 \%)$.

Dari seluruh peserta, $55,6 \%$ menjawab tidak terdapat kendala pada saat mengimplementasikan hasil pendampingan pembelajaran daring dan sisanya 44,4\% menjawab terdapat kendala. Kendala yang dirasakan adalah kendala yang tidak berkaitan dengan proses pendampingan, melainkan kendala yang berhubungan dengan infrastuktur jaringan internet (akses wifi) oleh orang tua siswa.

Seluruh peserta pendampingan pembelajaran daring memberikan respon bahwa, kegiatan tersebut sudah cukup baik dan berharap penyelanggaraan kegiatan pendampingan pembelajaran dapat dilaksanakan dengan tatap muka dan berlanjut pada pelatihan lanjutan secara berkala karena waktunya yang sangat terbatas

\section{KESIMPULAN DAN REKOMENDASI}

Dari kegiatan Pengabdian Pendampingan Pembelajaran Daring Saat Pandemi Covid-19 Bagi Guru-Guru YPKPI Baiturrahman Semarang dapat diberikan kesimpulan bahwa dalam kegiatan pembelajaran daring, 60\% guru-guru di lingkungan YPKPI Masjid Raya Baiturrahman Jawa Tengah menggunakan kombinasi antara smartphone dan komputer/laptop, 35\% menggunakan komputer /laptop dan sisanya menggunakan perangkat smartphone. Proses identifikasi peserta pelatihan diperoleh dengan menggunakan metode penelusuran hasil pengisian kuisioner yang telah dbagikan secara daring dan diperoleh 10 orang peserta pelatihan. Aplikasi Zoom merupakan platform aplikasi yang paling banyak digunakan dalam pembelajaran daring. Seluruh peserta pelatihan menyatakan bahwa kegiatan pendampingan pelatihan sangat bermafaat dan telah diimplementasikan para guru dalam proses pembelajaran secara daring, sedangkan kendala yang dimiliki peserta adalah kendala yang berkaitan dengan infrastruktur jaringan internet.

\section{Ucapan Terima Kasih}

Terima kasih untuk Yayasan Pusat Kajian dan Pengembangan Islam (YPKPI) Masjid Raya Baiturrahman Jawa Tengah, KB/TK Hj. Isriati Baiturrahman 1 dan 2, SD Hj. Isriati Baiturrahman 1 dan 2, SMP Hj. Isriati Semarang dan SMK Islamic Center Mayaran Semarang atas kerjasamanya dalam sinergi kegiatan pengabdian masyarakat dengan Program Studi Teknik Elektro, Universitas Islam Sultan Agung Semarang. 


\section{DAFTAR PUSTAKA}

Isman, M. (2017). Pembelajaran Moda dalam Jaringan (Moda Daring). The Progressive and Fun Education Seminar, 586-588.

Kuntarto, E. (2017). Keefektifan Model Pembelajaran Daring Dalam Perkuliahan Bahasa Indonesia Di Perguruan Tinggi. Journal Indonesian Language Education and Literature, $3(1), \quad 99-110 . \quad$ Retrieved http://www.syekhnurjati.ac.id/jurnal/index.php/jeill/\%0APEMBELAJARAN

Mardiana, T., \& Arif Wiyat Purnanto. (2017). Google Form Sebagai Alternatif Pembuatan Latihan Soal Evaluasi. Universty Research Colloquium, 183-188.

Menteri Pendidikan dan Kebudayaan Republik Indonesia. (2020). Pembelajaran secara Daring dan Bekerja dari Rumah dalam Rangka Pencegahan Penyebaran Corona $\begin{array}{llll}\text { Virus Disease (COVID-19). Retrieved } & & \end{array}$ https://bersamahadapikorona.kemdikbud.go.id/surat-edaran-mendikbud/

Pramasdyahsari, A. S., Sutrisno, S., Setyawati, R. D., Rahmawati, N. D., \& Endawuri, D. (2020). Blended Learning: Workshop Penggunaan Google Form dan Google Classroom Bagi Guru SMP Negeri 34 Semarang. Bakti Cendana, 3(1), 43-49. https://doi.org/10.32938/bc.v3i1.450

Sadikin, I. S., Lestari, S., \& Aini, S. (2020). Pembelajaran Daring Interaktif , Bermakna dan Menarik sebagai Upaya Optimalisasi Proses Pembelajaran masa Pandemi Covid-19. Jurnal Pengabdian Pada Masyarakat, 5(4), 897-905.

Siahaan, S. (2008). Peranan E-Learning Dalam Kegiatan Pembelajaran. Jurnal Transformatika, 6(1), 40. https://doi.org/10.26623/transformatika.v6i1.31

Suminingsih. (n.d.). Aplikasi Zoom Cloud Meetings Maksimalkan Belajar di Rumah. Retrieved April 19, 2020, from https://poskita.co/2020/03/24/aplikasi-zoom-cloudmeetings-maksimalkan-belajar-di-rumah/

Wicaksono, V. D., \& Rachmadyanti, P. (2016). Pembelajaran Blended Learning melalui Google Classroom di Sekolah Dasar. Seminar Nasional Pendidikan PGSD UMS \& HDPGSDI Wilayah Timur, 513-521. Retrieved from http://hdl.handle.net/11617/9144

Yayasan Pusat Kajian dan Pengembangan Islam (YPKPI) Masjid Raya Baiturrahman Jawa Tengah. (2012). Unit Sekolah YPKPI. Retrieved December 12, 2020, from http://ypkpi-jateng.org/ 